DOI: $10.19195 / 0137-1134.110 .3$

JERZY ZAJADŁO

Uniwersytet Gdański

\title{
PRAWOZNAWSTWO - POLITYCZNOŚĆ NAUKI CZY NAUKA POLITYCZNOŚCI?
}

Kiedy dyskutuje się nad problemem polityczności nauki prawa, to trudno oczywiście abstrahować od filozofii politycznej Carla Schmitta. Wprawdzie we współczesnej politologii przyjmuje się, że wprowadzone przez tego autora „pojęcie polityczności” (Begriff des Politischen $)^{1}$ jest czymś innym niż sama ,polityka” i jeszcze czymś innym niż mogące brzmieć na pierwszy rzut oka nieco pejoratywnie „upolitycznienie"2, jednak na potrzeby tego opracowania traktuję je synonimicznie.

Taki zabieg jest wprawdzie trochę pod prąd współczesnej metodologii nauk społecznych, ale intuicyjnie wyczuwam, że autorom tematu XXII Zjazdu Katedr Teorii i Filozofii Prawa, „Polityczność nauki i praktyki prawniczej”, chodziło po trochę o każdy z tych fenomenów, w związku z tym nie ma potrzeby zachowywania jakiegoś szczególnego terminologicznego puryzmu. Tym bardziej, że ani polityka, ani polityczność, ani upolitycznienie nie są pojęciami jednoznacznymi. Kiedy bowiem mówimy „polityka”, może to oznaczać np. zarówno Arystotelesowskie działanie na rzecz dobra wspólnego, jak i Weberowski proces zdobywania i utrzymania władzy. Kiedy wspominamy o „polityczności”, to nie wiadomo, czy chodzi nam np. o Schmittowską rywalizację przyjaciół i wrogów, czy wspólne działanie w sferze publicznej w rozumieniu Hannah Arendt. Kiedy zastanawiamy się nad istotą ,upolitycznienia”, to nasuwa się z kolei pytanie, czy mamy na myśli np. subiektywne i przygodne zaangażowanie w spór polityczny, czy może obiektywne i konieczne wypełnianie pewnego fenomenu treścią polityczną. Sprawa komplikuje się jeszcze bardziej, gdy pytamy o polityczność/związki z polityką/

${ }^{1}$ C. Schmitt, Teologia polityczna i inne pisma, przeł. M. Cichocki, Warszawa 2012 (1. wyd. Kraków-Warszawa 2000).

2 M. Karwat, Polityczność i upolitycznienie. Metodologiczne ramy analizy, „Studia Politologiczne” 17, 2010, s. 63-88; trzeba podkreślić, że w ostatnim czasie mamy do czynienia ze wzmożonym zainteresowaniem problemem relacji między polityką i politycznością, por. np. Polityka i polityczność. Problemy teoretyczne i metodologiczne, red. A. Czajkowski, L. Sobkowiak, Wrocław 2012; oraz tematyczny tom „Studiów Politologicznych” 37, 2015: Polityczność i polityka w refleksji teoriopolitycznej. 
upolitycznienie nauki, w tym także (a może zwłaszcza) nauki prawa ${ }^{3}$. Teza o tym, że materia prawoznawstwa ma charakter polityczny, jest tak oczywista, że trąci banałem. A jaka ma być, skoro prawo powstaje w procesie politycznym, reguluje kwestie polityczne, łączy się z państwem, jest instrumentem uprawiania polityki etc.? To jednak nie przesądza jeszcze ostatecznie o odpowiedzi na pytanie postawione w tytule tego opracowania. Spróbujmy to więc prześledzić na przykładzie biografii i twórczości autora Begriff des Politischen, ponieważ to pytanie postawione akurat pod jego adresem $\mathrm{z}$ różnych względów nabiera dopiero prawdziwego znaczenia.

We współczesnej nauce panuje określona, moim zdaniem nieco jednostronna, interpretacja koncepcji Carla Schmitta - do pewnego stopnia narzucili ją nam, prawnikom, współcześni konserwatywni filozofowie polityki. Można jednak spróbować innego odczytania myśli niemieckiego uczonego, zwłaszcza w tej sferze, która dotyczy nie polityki, władzy, dyktatury czy suwerenności, lecz właśnie prawa i prawoznawstwa ${ }^{4}$. Tym bardziej, że we współczesnej filozofii polityki ${ }^{5}$, ergo - po części także w filozofii prawa, chyba nikt inny nie wywołuje takich emocji i kontrowersji, fascynacji i negacji, uprzedzeń i zaufania, oskarżeń i usprawiedliwień, jednoznaczności i wątpliwości, co Carl Schmitt. Po części wynika to z jego poglądów, a po części z jego biografii; po części ze zbytniej dosłowności interpretacyjnej badaczy, a po części z ich skłonności do nadinterpretacji; po części z metodologicznej postawy historycznej determinacji kontekstu, a po części z ahistorycznego uniwersalizmu idei. W związku z tym w wypadku Carla Schmitta być może nic nie jest pewne - ani założenia, ani wnioski; ani obiektywna metodologia, ani subiektywna ocena; ani przyczyny, ani skutki; ani sprzeczność, ani spójność; wreszcie - ani pełna prawda, ani kompletny fałsz. Może dlatego, że

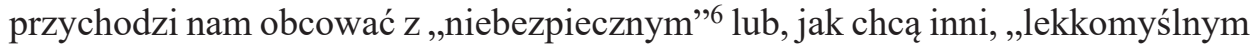
umysłem""? Może dlatego, że z jednej strony mamy do dyspozycji bezpośrednie źródła w postaci prac Schmitta, z drugiej zaś - jego liczne osobiste interpretacje

${ }^{3}$ M. Paździora, M. Stambulski, Co może dać nauce prawa polityczność? Przyczynek do przysztych badań, „Archiwum Filozofii Prawa i Filozofii Społecznej”2014, nr 1, s. 55-66.

${ }^{4}$ Sam podjąłem ostatnio taką próbę, tłumacząc na język polski i komentując niewielką pracę Schmitta z 1934 roku O trzech rodzajach myślenia w nauce prawa, zob. J. Zajadło, Schmitt, Sopot 2016.

${ }^{5}$ Być może należałoby raczej mówić o filozofii politycznej, ale na potrzeby tego opracowania pomijam różnice między tymi pojęciami i traktuję je synonimicznie; osobnym problemem jest natomiast przypadek samego Carla Schmitta i jego specyficzna teologia polityczna - H. Meier, Four Chapters on the Distinction between Political Theology and Political Philosophy, Expanded Edition, Chicago-London 2011.

${ }^{6}$ Taki tytuł nosi monografia J.-W. Müllera, A Dangerous Mind: Carl Schmitt in Post-War European Thought, New Haven 2003.

7 Taki tytuł nosi tematyczny numer „Przeglądu Politycznego” 2014, nr 127/128. 
i wyjaśnienia ${ }^{8}$, w których w pewnym samoobronnym odruchu próbuje wythumaczyć sens swoich poglądów i swoich życiowych wyborów, z zeznaniami złożonymi przed amerykańskimi władzami okupacyjnymi włącznie? Może wreszcie dlatego, że zawsze w sposób subiektywny będziemy nakładać na jego poglądy i biografię kalkę własnych etycznych, politycznych czy prawnych preferencji? Tak czy inaczej - chyba już na zawsze pozostanie dla jednych postacią intelektualnie heroiczną, dla innych moralnie żałosną, z niezliczoną liczbą różnych odcieni szarości pośrodku. Jednak prawda o Schmitcie, zarówno ta kompletnie dyskwalifikująca, jak i ta bezkrytycznie apologetyczna, jest ciągle prawdą cum grano salis.

$\mathrm{Na}$ temat filozofii polityki Carla Schmitta napisano i wydano już tyle monografii, prac zbiorowych, antologii tekstów, artykułów, esejów, recenzji, komentarzy, wspomnień itp., że można by tym zapełnić sporych rozmiarów bibliotekę9 Nie ma więc sensu silić się w tym miejscu nawet na ich przykładowe wyliczenie, tym bardziej że czytelnik może z łatwością odnaleźć w sieci mniej lub bardziej rozbudowane zestawienia bibliograficzne. Spowodowany różnymi czynnikami renesans jego myśli w ciągu ostatnich kilkunastu lat dodatkowo tylko komplikuje sytuację - podobno nie ma miesiąca, by nie ukazała się ten temat jakaś nowa publikacja naukowa, i to dotycząca różnych kontekstów — historii myśli polityczno-prawnej, teorii polityki, liberalizmu i demokracji, wroga i przyjaciela, modelu państwa, istoty prawa i bezprawia, legalizmu i legitymacji, konstytucjonalizmu, suwerenności, terroryzmu międzynarodowego, stosunków międzynarodowych, konfliktów zbrojnych etc. Ciągle podejmuje się próby oceny współczesnej aktualności myśli Schmitta i możliwości jej praktycznego wykorzystania ${ }^{10}$. Zainteresowanie budzi też ciekawa i skomplikowana biografia niemieckiego uczonego ${ }^{11}$.

$\mathrm{Z}$ punktu widzenia głównego tematu tego opracowania najciekawsze jest jednak to, że ostatnio podjęto próbę rekonstrukcji sylwetki Schmitta jako prawnika ${ }^{12}$. Towarzyszy temu też stawianie pytania, czy istnieje w ogóle coś takiego, jak filozofia (teoria) prawa Carla Schmitta, a jeśli tak, to jakie jest jej miejsce w filozofii polityki tego autora ${ }^{13}$. Ten temat jest jednak tak obszerny i skomplikowany, że jego szczegółowa analiza znacznie przekraczałaby ramy tego krótkiego szkicu. Dla uproszczenia skupmy się więc tylko na dwóch bardzo osobistych wyzna-

8 Chodzi zwłaszcza o C. Schmitt, Glossarium. Aufzeichnungen der Jahre 1947-1951, Berlin 1991 (zwróćmy uwagę, że niedawno ukazało się nowe wydanie (Berlin 2015), które jest rozszerzone o notatki Schmitta aż do 1958 roku).

${ }^{9}$ Bibliografia prac Schmitta i literatury na jego temat liczy sobie ponad 500 stron (!) - A. de Benoist, Carl Schmitt. Internationale Bibliographie der Primär- und Sekundärliteratur, Graz 2010.

${ }_{10}$ Por. np. The Contemporary Relevance of Carl Schmitt. Law, Politics, Theology, red. M. Arvidsson, L. Brännström, P. Minnkinen, New York 2016.

11 R. Mehring, Carl Schmitt. Aufstieg und Fall. Eine Biographie, München 2009.

12 V. Neumann, Carl Schmitt als Jurist, Tübingen 2015.

13 J. Zajadło, Filozofia (teoria) prawa Carla Schmitta?, „Przegląd Sejmowy” 2016, nr 4, s. $65-94$. 
niach Schmitta, które są tak zagadkowe, że mogą budzić zainteresowanie właśnie z punktu widzenia postawionego w tytule pytania: prawoznawstwo - polityczność nauki czy nauka polityczności?

Pierwsze pochodzi z rozliczeniowego eseju Ex Captivitate Salus, który Schmitt opublikował w 1950 roku, a więc w trzy lata po wyjściu z niewoli amerykańskich władz okupacyjnych:

Działalność naukowa uczonego uprawiającego prawo publiczne - niejako samo jego dzieło — sytuuje go w określonym kraju, w obrębie określonych środowisk i sił, w określonym kontekście czasowym. Materia, z której tworzy swoje pojęcia, i na którą jest zdany w swojej naukowej działalności, wiąże go z sytuacjami politycznymi, których pomyślność albo niepomyślność, szczęście bądź nieszczęście, zwycięstwo lub klęska zagarniają również samego badacza i teoretyka, rozstrzygając o jego osobistym losie ${ }^{14}$.

Możemy, jak sądzę, słowa Schmitta potraktować nieco szerzej, w kontekście nauk prawnych w ogóle (prawoznawstwa) i nie ograniczać się wyłącznie do prawa publicznego.

Jeszcze bardziej zaskakująco brzmi druga $\mathrm{z}$ wypowiedzi. W wywiadzie udzielonym w 1983 roku (a więc na dwa lata przed śmiercią) niemiecki uczony zwierzył się Fulco Lanchesterowi: „Czuję się w stu procentach prawnikiem i nikim innym. I nie chcę być kimś innym. Jestem prawnikiem, nim pozostanę i umrę też jako prawnik, z całym nieszczęściem prawnika, jakie się z tym wiąże"15. To rzeczywiście zaskakujące wyznanie, jeśli zważymy sławę Schmitta przede wszystkim jako filozofa polityki, a zwłaszcza teoretyka stanu wyjątkowego.

Wbrew pozorom istnieje jednak pewien związek między filozofią polityki Carla Schmitta a jego ogólną refleksją nad prawem, nawet jeśli ta ostatnia nie jest zbyt rozbudowana i poparta większymi opracowaniami naukowymi tego autora. Schmitt miał manierę rozpoczynania swoich prac od bardzo silnego akcentu. Przypomina to trochę znaną w teorii kinematografii słynną tezę Alfreda Hitchcocka: „Film powinien zaczynać się od trzęsienia ziemi, potem zaś napięcie ma nieprzerwanie rosnąć". W Teologii politycznej z 1922 roku jako pierwsze pojawia się chyba najsłynniejsze i wywołujące najwięcej emocji zdanie Schmitta: „Suwerenny jest ten, kto decyduje o stanie wyjątkowym"16. Praca Rzymski katolicyzm i polityczna forma z 1923 roku rozpoczyna się od kontrowersyjnej i wielokrotnie komentowanej opinii: „Rzym, jako symbol papiestwa i imperium, często wywołuje uczucia negatywne"17. W opracowaniu Pojęcie polityczności z 1932 roku (pierwotnie w 1927 roku w formie artykułu) brzmi to w sposób po dziś dzień rozpalający emocje i wyobraźnię politologów: „Pojęcie państwa zakłada pojęcie

14 C. Schmitt, Ex Captivitate Salus, przeł. A. i A. Klubowie, „Przegląd Polityczny” 2014, nr 127/128, s. 68.

15 Ostatnia rozmowa. Prawnik przed samym soba, przeł. K. Burzyk, „Przegląd Polityczny” 2014, nr 127/128, s. 223.

${ }^{16}$ C. Schmitt, Teologia polityczna..., s. 45.

17 Ibidem, s. 105. 
polityczności"18. Wreszcie, w jedynym tak naprawdę filozoficzno-prawnym dziele Schmitta, cytowanej już pozycji O trzech rodzajach myślenia w nauce z 1934 roku, taką rolę początkowego „trzęsienia ziemi” pełni zdanie: „Każdy prawnik, który w swojej pracy, świadomie bądź nieświadomie, opiera się na pojęciu ,pra$w a$ ', uważa to prawo albo za regute, albo za rozstrzygnięcie, albo za konkretny porzadek i tworzenie [kursywa w oryginale - J.Z.]"19.

Wbrew pozorom jest w tym pewne iunctim. Osławiony suweren z Teologii politycznej, zdolny i władny do wprowadzenia stanu wyjątkowego, przez jednych pojmowany jest dosłownie, przez innych — symbolicznie. Wszystko, zwłaszcza to, co Schmitt pisze o Hobbesie, wskazuje jednak na to, że ta druga interpretacja jest właściwsza i bliższa prawdy. Schmittowi nie chodzi o permanentny stan wyjątkowy, lecz o moment początkowy, o punkt startu, o rozstrzygnięcie, które kreuje nowy porządek polityczno-prawny od punktu zero, z „niczego”. To symboliczne „nic” oznacza tylko kompletną pierwotność początkowej legitymacji, nie oznacza natomiast jej całkowitej arbitralności — także symboliczny Leviathan jest zdeterminowany zakorzenionym w bycie nomosem. Po "wyjątkowym stanie” pierwotnej decyzji, pierwotnego rozstrzygnięcia przychodzi jednak „,normalność”, która jest naturalnym środowiskiem prawa jako głównego składnika konkretnego porządku i polityki pojętej w kategoriach działania na rzecz dobra wspólnego. Do czasu, gdy ów porządek nie utraci swojej legitymacji i gdy znowu nie trzeba będzie podjąć decyzji w warunkach pierwotnego „wyjątkowego stanu”, by rozpocząć budowę nowego porządku od tak pojętego „nic”. Jeśli powiążemy filozofię polityki Schmitta z jego, wprawdzie dosyć zdawkową, ale jednak, ogólną refleksją nad istotą prawa, okazuje się, że poszukuje on przede wszystkim warunków oraz możliwości stworzenia, istnienia i utrzymania stabilnego porządku polityczno-prawnego. Związek między legalnością i legitymacją staje się więc immanentny, ale tylko wówczas, gdy w warunkach „normalności” nie istnieje prymat prawa nad polityką i polityki nad prawem. Innymi słowy — gdy prawo i polityka są nieodłącznymi i powiązanymi z sobą komponentami tak pojętego stabilnego konkretnego porządku. Jaką treścią wypełnimy to prawo, tę politykę i w rezultacie ten konkretny porządek, to już zupełnie inna sprawa, chodzi o mechanizm.

Refleksja nad tymi dwoma cytowanymi, przyznaję - nieco wyrwanymi z szerszego kontekstu, bardzo osobistymi opiniami Schmitta skłania jednak do wniosku, że problem związku nauki prawa z polityką (politycznością/upolitycznieniem) może mieć dwa aspekty. Po pierwsze, może oznaczać zaangażowanie prawoznawstwa w bieżącą politykę i uczynienie z niego instrumentu walki politycznej, co z punktu widzenia istoty i etosu nauki nie wydaje się ani właściwe, ani pożądane (polityczność nauki). Po drugie, powinna oznaczać zrozumienie koniecznych związków prawa z polityką, bez jednoczesnej instrumentalnej party-

18 Ibidem, s. 245.

19 J. Zajadło, op. cit., s. 69. 
cypacji w bieżących sporach politycznych, co z punktu widzenia tzw. zewnętrznej i wewnętrznej integracji prawoznawstwa wydaje się nie tylko pożądane, lecz wręcz konieczne (nauka polityczności).

Schmitt, głównie z różnych przyczyn biograficznych i charakterologicznych, a nie przede wszystkim merytorycznych czy ideologicznych, balansował na granicy między tymi dwoma postawami - właśnie dlatego był w stanie tak łatwo przejść od obrony weimarskiego porządku konstytucyjnego (Legalność i prawomocność z 1932 roku $^{20}$ ) do aktywnego poparcia reżimu nazistowskiego (Führer jest obrońca prawa, 1934 roku $^{21}$ ). Z powodu dramatycznego wyboru skończył się dla niego język prawniczy prawoznawstwa wyłącznie jako nauki polityczności, ponieważ zaczął się on mieszać z żargonem upolitycznionej nauki prawa jako propagandy. To już nie prezydent jest strażnikiem konstytucji; w to miejsce, ale już w zupełnie nowej roli, wkracza wódz: „Führer jest obrońcą prawa przed najgorszego rodzaju nadużyciem, gdy w chwili zagrożenia, na mocy swojego przywództwa (Führertum) jako najwyższy sędzia tworzy prawo"22. To jednak musiało z konieczności oznaczać złamanie paradygmatu dotychczasowego prawoznawstwa.

W związku z tym w wypadku Schmitta znak zapytania postawiony w tytule tego opracowania jest $\mathrm{w}$ gruncie rzeczy bezzasadny. Od pewnego momentu dla Schmitta prawoznawstwo było bowiem zarówno nauką polityczności w znaczeniu koniecznych związków prawa z polityką z powodów metodologicznych, jak i politycznością nauki w znaczeniu możliwości jego wykorzystania do bieżących sporów politycznych z powodów pozanaukowych.

Ten ambiwalentny skutek, który stał się udziałem Carla Schmitta z jego własnego wyboru, nie jest jednak jakimś fatum, na które jesteśmy skazani. To nieprawda, że uczony uprawiający naukę prawa jest skazany na politykę/polityczność/upolitycznienie per fas et nefas. To, że Schmitt z różnych powodów dokonał takiego wyboru i że połączył te dwie perspektywy, nie oznacza jeszcze, że tak musi być, a tym bardziej, że tak być powinno. Jego przypadek pozwala jednak na sformułowanie pewnej ogólnej tezy — wydaje się, że niebezpieczeństwo instrumentalnego upolitycznienia prawoznawstwa jest wprost proporcjonalne do autorytarnych zapędów władzy. Niemiecki historyk prawa Jan Schröder w swoim obszernym dziele ${ }^{23}$ pokazuje proces nowożytnego rozwoju prawoznawstwa, głównie niemieckiego, jako nauki w latach 1500-1933 — jest to właściwie obraz stopniowego i powolnego uwalniania prawoznawstwa od wpływów zewnętrz-

20 C. Schmitt, Legalność i prawomocność, przeł. B. Baran, Warszawa 2015.

${ }^{21}$ Pierwotnie opublikowano w „Deutsche Juristen-Zeitung”, Jg. 39, Heft 15, z 1 sierpnia 1934 roku, szp. 945-950 (zwróćmy uwagę, że Schmitt powtarza tam dosłownie wypowiedź Hitlera z jego słynnej mowy w Reichstagu z 13 lipca 1934 roku i w pełni się z nią identyfikując, przenosi ją na grunt rozważań teoretycznych) — polskie thumaczenie P. Graczyk, „Kronos” 2010, nr 2, s. 63-67.

22 Cytuję według wydania polskiego, ibidem, s. 65.

23 J. Schröder, Recht als Wissenschaft. Geschichte der juristischen Methodenlehre in der Neuzeit (1500-1933), München 2012. 
nych (w tym także od polityki), które swoje karykaturalne apogeum osiągnęło w pozytywizmie prawniczym, zwłaszcza w jurysprudencji pojęciowej (Begriffsjurisprudenz) Karla Bergbohma. Charakterystyczna jest końcowa data okresu objętego analizą - 1933 rok. W ostatnim czasie niemiecki uczony dopisał jednak suplement do tej historii ${ }^{24}$ - tutaj przedstawia ten sam proces, tyle że á rebours, na przykładzie gigantycznego instrumentalnego upolitycznienia prawoznawstwa na potrzeby dyktatorskich reżimów w nazistowskiej Rzeszy i w komunistycznej NRD. Dzisiaj już wiemy, że ani przesadna autonomia metodologiczna, ani tym bardziej polityczna instrumentalizacja nie są dobrymi pomysłami na prawoznawstwo, które może i powinno się otwierać na inne dziedziny naukowe bez jednoczesnej utraty specyfiki swojego przedmiotu i swoich metod ${ }^{25}$. Ta wiedza płynie jednak właśnie z negatywnych doświadczeń.

Instrumentalne upolitycznienie prawoznawstwa, naruszające jego utrwalone przez stulecia paradygmaty, występuje jednak nie tylko w reżimach totalitarnych, może się też incydentalnie przytrafić w ustrojach demokratycznych, gdy z różnych powodów władza wykonawcza zaczyna przejawiać autorytarne apetyty i naruszać zasady państwa prawa oraz podziału władzy. Typowym przykładem wydaje się sytuacja w USA w okresie początków walki z terroryzmem za prezydentury George'a W. Busha. Tocząca się tam wówczas dyskusja na temat możliwości i dopuszczalności stosowania tortur wobec schwytanych terrorystów uwikłała wielu amerykańskich prawników, w tym także uczonych, w proceder świadczący ewidentnie o próbie instrumentalnego upolitycznienie prawoznawstwa ${ }^{26}$. Złamali bowiem, podobnie jak kiedyś mutatis mutandis Schmitt, podstawowy paradygmat - zamiast mówić i pisać to, czego wymagało prawo, mówili i pisali to, czego oczekiwał i co chciał usłyszeć ich mocodawca. Kiedy sprawa wyszła na jaw, podjęto próbę opracowania na nowo kodeksu doradcy władz publicznych. Prawoznawstwo może bowiem oczywiście, a niekiedy nawet wręcz powinno, służyć swoją radą i pomocy władzom publicznym, ponieważ jest nauką polityczności. By jednak przy tym nie upolitycznić instrumentalnie tej nauki w sensie pejoratywnym, należy przestrzegać pewnych zasad deontologicznej etyki prawniczej27. Oto one:

1) rzetelna i uczciwa opinia o obowiązującym prawie,

2) wszechstronna informacja o prawnych ograniczeniach władzy,

24 J. Schröder, Rechtswissenschaft in Diktaturen. Die juristischen Methodenlehre im NS-Staat und in der DDR, München 2016.

25 J. Stelmach, B. Brożek, Metody prawnicze. Logika - analiza - argumentacja - hermeneutyka, Warszawa 2006.

26 J. Zajadło, Dyskusja na temat tortur w Stanach Zjednoczonych Ameryki, PiP 2006, z. 5, s. 32-47; oraz idem, Po co prawnikom filozofia prawa, Warszawa 2008, s. 30-54.

27 J. Zajadło, Etyka doradcy władz publicznych (na przykładzie afery tzw. torture papers), „Przegląd Sejmowy” 2007, nr 6, s. 231-244. 
3) szczególna odpowiedzialność ze względu na brak sądowej kontroli doradztwa,

4) uwzględnianie $z$ jednej strony bieżącej polityki, z drugiej zaś dotychczasowej tradycji,

5) uwzględnianie stanowiska wszystkich trzech władz w ramach podziału władzy,

6) jasność i pisemna forma opinii,

7) najwyższa profesjonalna jakość doradztwa,

8) uwzględnianie wszystkich istniejących opinii,

9) uprzedni charakter opinii w stosunku do decyzji mocodawcy,

10) działanie w granicach kompetencji.

Płynie z tego pouczająca lekcja dla polskich prawników biorących aktywny udział w sporze wokół Trybunału Konstytucyjnego. Prawoznawstwo jako nauka polityczności nie musi, a nawet z pewnością wręcz nie powinno, oznaczać polityczności nauki. Nauka prawa nie nadaje się bowiem na koniunkturalny instrument w bieżącej walce politycznej — uczony wprawdzie nie musi być politycznie czy światopoglądowo bezstronny, musi jednak kierować się metodologicznym obiektywizmem ${ }^{28}$. Możemy oczywiście zmieniać przyjęte paradygmaty, pod warunkiem wszakże, że taka zmiana jest efektem np. nowych odkryć, wnikliwych badań czy konsensusu osiągniętego w procesie racjonalnego naukowego dyskursu. Mówiąc nieco ironicznie - jeśli badania dowiodą, że najlepsze rezultaty interpretacyjne osiąga się, czytając akt prawny od tyłu, przyjmę to z pokorą. $\mathrm{Na}$ razie jednak pozostaję wierny dotychczasowym ustaleniom nauki prawa. Trudno mnie więc przekonać, że np. art. 190 ust. 5 konstytucji można zmienić w drodze ustawy zwykłej, a taki argument pojawiał się przecież przez długi czas w sporze o Trybunał Konstytucyjny, i to nie tylko w ustach polityków, lecz także w opiniach uczonych prawników. Nie wolno nam więc dokonywać doraźnego poświęcenia tych paradygmatów w celu osiągnięcia doraźnych celów politycznych, ponieważ w przeciwnym wypadku prawoznawstwo przestaje być nauką czy nawet wysoko profesjonalnym rzemiosłem, staje się kuglarstwem oraz stekiem koniunkturalnych bzdur i bredni zatopionych w sosie polityki/polityczności/upolitycznienia ${ }^{29}$. Losy nauki prawa w ustrojach totalitarnych wydają się tego dosadnym przykładem. W polskim prawoznawstwie ta przeszłość nie jest przecież wcale aż tak odległa, by o niej nie pamiętać.

28 L. Morawski, Państwo prawa, filozoficzna i moralna odpowiedzialność naukowców, „Archiwum Filozofii Prawa i Filozofii Społecznej” 2014, nr 2, s. 85-94.

29 J. Zajadło, ,, Nowa” PiS-owska nauka prawa, ,Gazeta Wyborcza” z 29 grudnia 2015 roku. 


\section{JURISPRUDENCE - THE POLITICAL OF SCIENCE OR SCIENCE OF THE POLITICAL?}

\section{Summary}

Considering the main subject of XXII Congress of the Chairs of Theory and Philosophy of Law the author tries to answer the following question: "Jurisprudence - the political of science or science of the political?". His answer is clear - we need the latter and not the former. In the article the concepts of ,politics”, ,political” and „politization” are treated synonymously.

The problem is presented on the background of Carl Schmitt's political philosophy. In the author's opinion after 1933 Schmitt has balanced between these two attitudes (the political of science or science of the political) because of his methodology (political theology) on the one hand, and of his personal choice (support for Nazi regime) on the other.

In the last part of the article are formulated some conclusions - learned from Schmitt's lesson and concerning the constitutional crisis in Poland. 